\title{
Preventive effects of Cyclosporin on diabetes in NOD mice
}

\author{
Y. Mori ${ }^{1}$, M. Suko ${ }^{2}$, H. Okudaira ${ }^{3}$, I. Matsuba ${ }^{1}$, A. Tsuruoka ${ }^{1}$, A. Sasaki ${ }^{1}$, H. Yokoyama ${ }^{1}$, T. Tanase ${ }^{1}$, T. Shida ${ }^{2}$, \\ M. Nishimura ${ }^{4}$, E. Terada ${ }^{5}$ and Y.Ikeda ${ }^{1}$ \\ ${ }^{1}$ Third Department of Internal Medicine, The Jikei University, Tokyo, ${ }^{2}$ Research Center for Rheumatology and Allergy, National Sagamihara \\ Hospital, Kanagawa, ${ }^{3}$ Department of Medicine and Physical Therapy, The University of Tokyo, Tokyo, ${ }^{4}$ The Animal Institute of Hamamatsu \\ Medical College, Shizuoka, and ${ }^{5}$ Laboratory of Life Sciences, School of Hygienic Sciences, Kitasato University, Kanagawa, Japan
}

Summary. Non-obese diabetic mice aged 30 to 60 days were treated orally with Cyclosporin at doses of 25,15 and $2.5 \mathrm{mg} /$ $\mathrm{kg}$ every 2 days until 160 days of age. Diabetes developed in 12 out of 18 oil-treated mice (67\%), with partial to complete Langerhans' islet destruction associated with lymphocytic infiltration. The non-obese diabetic mice showed a plasma glucose concentration of $6.62 \pm 0.92 \mathrm{mmol} / 1$ (mean $\pm \mathrm{SD}$ ) at 50 days of age. The plasma glucose level of oil-treated nonobese diabetic mice gradually increased after 130 days of age and reached 14.0 to $19.0 \mathrm{mmol} / 1$ at 160 days of age, while Cyclosporin-treated non-obese diabetic mice showed neither clear increase of plasma glucose levels nor development of insulitis. The cumulative incidence of diabetes in Cyclosporintreated mice was significantly lower than that in oil-treated mice $(p<0.01)$. Subsequently, Cyclosporin treatment was started after development of glucose intolerance. Twenty-five $\mathrm{mg} / \mathrm{kg}$ of Cyclosporin was administered every 2 days for 35 days. Cyclosporin appeared to have little therapeutic effect on diabetes in non-obese diabetic mice.

Key words: Cyclosporin, NOD mice, Type 1 diabetes, insulitis, autoimmunity.
The non-obese diabetic (NOD) mouse recently developed by Tochino and his colleagues [1] is a strain in which insulin-dependent, non-obese, ketotic diabetes mellitus develops spontaneously. There is marked mononuclear cell infiltration surrounding and/or invading Langerhans' islets, with resultant complete destruction of B cells. Insulitis begins to develop around 30 days of age, and at 140 days of age approximately $70 \%$ of female NOD mice develop diabetes. Diabetes in this mouse strain resembles Type 1 (insulin-dependent) diabetes in man.

Cyclosporin (Cs) is a fungal metabolite which has potent immunosuppressive effects without significant myelotoxicity [2]. In experimental animals, administration of $\mathrm{Cs}$ has been shown to remarkably prolong the survival of major histocompatibility complex incompatible organ allografts [3-6]. Recently, Laupacis et al. [7] reported that Cs suppressed the development of insulindependent diabetes mellitus in BB Wistar rats.

In the present study, we examined the ability of $\mathrm{Cs}$ to suppress and/or ameliorate diabetes mellitus in NOD mice.

\section{Materials and methods}

\begin{abstract}
Animals
Female NOD mice were provided by the Animal Institute of Hamamatsu Medical College, Japan. All mice were kept under conventional conditions at a constant temperature $\left(22-25^{\circ} \mathrm{C}\right)$ and fed a commercial diet (Clea Japan Inc., Tokyo, Japan) and tap water ad libitum.

\section{Cyclosporin}

Cs, (a gift from Sandoz Ltd., Basel, Switzerland), was dissolved in olive oil at a concentration of $15 \mathrm{mg} / \mathrm{ml}$ by stirring at $37^{\circ} \mathrm{C}$.
\end{abstract}

Disease detection. Blood samples were collected from the retroorbital sinus with hematocrit tubes every 2 weeks. Plasma glucose was assayed by the glucose-oxidase technique [8]. The onset of diabetes was defined by a random post-prandial plasma glucose concentration of over $11.0 \mathrm{mmol} / \mathrm{l}$.

\section{Experimental design}

Preventive effects of Cs. In the first experiment, six randomly selected 30-day-old NOD mice were orally administered $25 \mathrm{mg} / \mathrm{kg}$ of Cs in olive oil every 2 days until 160 days of age. Ten NOD mice of the same age served as controls and were given the same amount of olive oil. In the second experiment, 22 60-day-old NOD mice were randomly di- 
vided into three groups and given $15 \mathrm{mg} / \mathrm{kg}(n=7), 2.5 \mathrm{mg} / \mathrm{kg}(n=7)$ or no $(n=8)$ Cs every 2 days.

Therapeutic effects of Cs. Several NOD mice over 150 days of age were subjected to a glucose tolerance test. Each mouse was placed in an individual cage and fasted for 16 to $20 \mathrm{~h}$. Blood samples were obtained 0,30 and $120 \mathrm{~min}$ after intraperitoneal injection of glucose at a dose of $1 \mathrm{~g} / \mathrm{kg}$ of body weight (intraperitoneal glucose tolerance test: IPGTT). Onset of glucose intolerance was tentatively defined as an increase in the plasma glucose level to over $11.0 \mathrm{mmol} / \mathrm{l}$ after $30 \mathrm{~min}$ and over $8.25 \mathrm{mmol} / 1$ after $120 \mathrm{~min}$. The plasma glucose values after 0,30 and $120 \mathrm{~min}$ in non-diabetic female NOD mice were $6.64 \pm 1.31$, $8.84 \pm 0.94$ and $6.62 \pm 0.76 \mathrm{mmol} / \mathrm{l}$ respectively. Ten NOD mice with glucose intolerance were selected for the experiment. Twenty-five $\mathrm{mg} / \mathrm{kg}$ of $\mathrm{Cs}$ was administered every 2 days for 35 days.

\section{Histological examination}

All the mice were killed at 160 days of age. The pancreata, livers and kidneys were quickly removed under ether anaesthesia and fixed in $10 \%$ formalin solution. Paraffin-embedded sections were stained by hematoxylin and eosin (HE). The extent of lymphocytic infiltration (intensity of insulitis) in an islet was scored 0 to 3 , with 0 indicating normal islet morphology and absence of insulitis, 1 less than $25 \%$, 2 less than $50 \%$ and 3 greater than $50 \%$ histological alterations. The grade of insulitis in a mouse was expressed as the average score calculated by the following equation: grade of insulitis = total score/number of islets. About 20 different islets were examined per pancreas.

\section{Statistical analysis}

The data were expressed as mean \pm SD. Student's paired t-test was used for comparison of the plasma glucose levels. The Chi-squared test was used for comparison of the cumulative incidence of diabetes. A $p$-value of $<0.05$ was considered significant.

\section{Results}

\section{Cs prevention of diabetes development in NOD mice}

In the first experiment, seven out of $10(70 \%)$ oil-treated mice developed diabetes at 160 days of age, whereas none of the Cs-treated mice developed diabetes $(p<$ 0.01 ). In the second experiment at 160 days of age, five out of eight $(63 \%)$ oil-treated mice given no Cs developed diabetes, while none of the Cs-treated mice became diabetic at any oral dose $(p<0.01)$.

The plasma glucose levels in the oil-treated and Cstreated groups of mice are shown in Figure 1. The plasma glucose concentrations in Cs-treated animals remained under $11.0 \mathrm{mmol} / 1$ throughout the experiment and were significantly lower than those in oil-treated mice $(p<0.05)$.

Body weight of female NOD mice reached $19 \pm$ $1.7 \mathrm{~g}$ at 30 days of age and gradually increased to $27 \pm$ $2.5 \mathrm{~g}$ at 140 days of age. Thereafter, diabetes began to develop in oil-treated animals and body weight slowly decreased to $23 \pm 2.0 \mathrm{~g}$ at 160 days of age. Cs-treated mice maintained their body weight at $29 \pm 3.5 \mathrm{~g}$.

\section{Histological examination}

Pancreas sections of oil-treated NOD mice appeared normal with no lymphocytic infiltration at 30 days of
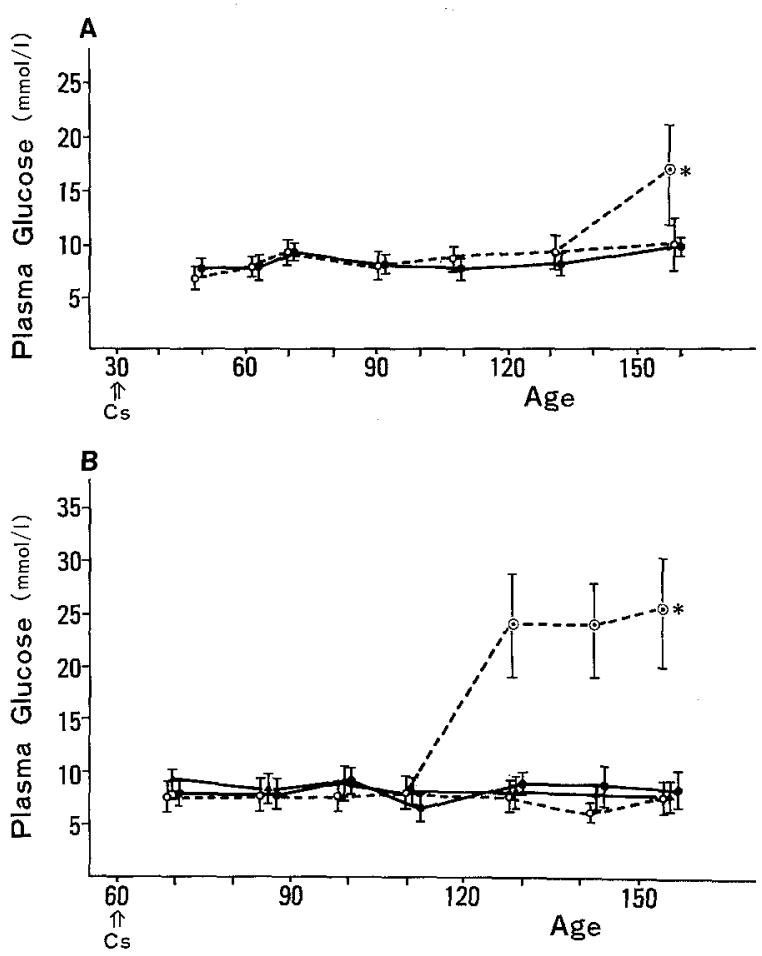

Fig. $1 \mathrm{~A}$ and B. Preventive effects of Cyclosporin (Cs) on the development of diabetes in NOD mice. A Experiment 1. Six 30-day-old NOD mice were orally administered $25 \mathrm{mg} / \mathrm{kg}$ of $\mathrm{Cs}(-)$ ) in olive oil every two days until 160 days of age. Ten NOD mice of the same age served as controls and were given the same amount of olive oil $(\mathrm{O}-\mathrm{O})$. Seven out of $10(70 \%)$ oil-treated mice developed diabetes $(\odot-\ldots)$, but the rest were free of diabetes $\left(O_{-}-O\right)$ at 160 days of age. None of the Cs-treated mice developed diabetes. ${ }^{*} p<0.05$. B Experiment 2 . Twenty-two 60-day-old NOD mice were randomly divided into three groups and given $15 \mathrm{mg} / \mathrm{kg}(n=7,0)$, $2.5 \mathrm{mg} / \mathrm{kg}(n=7, \boldsymbol{\Lambda})$ or no $\left(n=8, \bigcirc-\uparrow_{-} \odot \odot\right)$ Cs every 2 days. At 160 days of age, 5 out of $8(63 \%)$ control mice given no Cs developed diabetes $(\odot-\odot)$, but the rest remained free of diabetes $(\mathrm{O}--\mathrm{O})$. None of the Cs-treated mice became diabetic at any oral dose. $* p<0.01$

age. Mild insulitis was observed at 60 days of age. The pancreata of NOD mice given only olive oil showed destruction of Langerhans' islets with heavy lymphocytic infiltration at 160 days of age (Fig. $2 \mathrm{~A}$ ). In contrast, the pancreata of mice treated with $25 \mathrm{mg} / \mathrm{kg}$ of Cs from 30 days of age showed no or only mild insulitis at 160 days of age (Fig. 2B). The pancreata of mice treated with 15 and $2.5 \mathrm{mg} / \mathrm{kg}$ of Cs from 60 days of age also showed only mild insulitis. The pancreata of all oiltreated mice in this experiment at 160 days of age showed insulitis irrespective of whether or not they were diabetic. The grades of insulitis (average score) in oil-treated mice and Cs-treated mice at doses of 25,15 and $2.5 \mathrm{mg} / \mathrm{kg}$ were $1.65 \pm 0.28,0.15 \pm 0.22,0.59 \pm 0.12$ and $0.39 \pm 0.16$ respectively. The grade of insulitis was significantly decreased in Cs-treated mice at all oral doses compared with oil-treated mice $(p<0.01)$. At the doses of Cs used in this experiment, no tubular damage in the kidneys and no liver lesions were observed in the Cs-treated mice. 


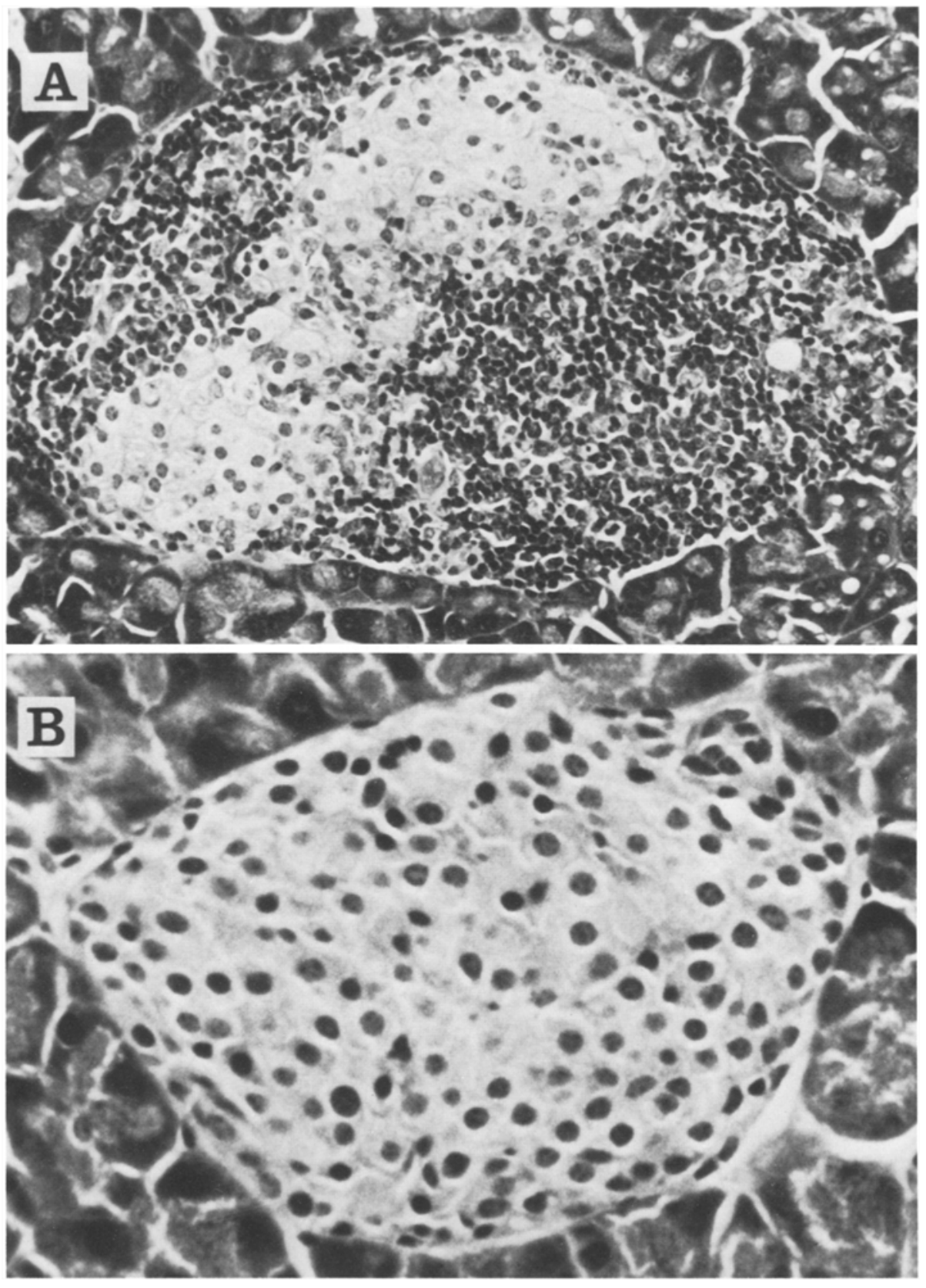

Fig. $2 A$ and B. Pancreata of Cs-treated and oil-treated mice were histologically examined at 160 days of age. A The pancreata of oil-treated NOD mice showed destruction of Langerhans' islets with severe lymphocytic infiltration. B In contrast, the pancreata of mice treated with $25 \mathrm{mg} / \mathrm{kg}$ of Cs from 30 days of age showed no insulitis

\section{Cs treatment of NOD mice with diabetes}

Five glucose intolerant NOD mice, whose fasting plasma glucose level ranged from 6.1 to $16.3 \mathrm{mmol} / 1$, showed a clear increase ( 10 to $35 \mathrm{mmol} / \mathrm{l}$ ) in fasting plasma glucose concentrations irrespective of the Cs treatment. The fasting plasma glucose level of one glucose intolerant mouse $(5.6 \mathrm{mmol} / 1)$ remained suppressed for 35 days by Cs treatment. Three of 4 mice with fasting plasma glucose levels over $33 \mathrm{mmol} / \mathrm{l}$ died during the experiment, while one mouse showed a consistent decrease in the fasting plasma glucose levels to $10.0 \mathrm{mmol} / 114$ days after Cs administration. However, the gradual elevation of the fasting plasma glucose level reached $20.4 \mathrm{mmol} / 135$ days after Cs treatment. Pan- creata of the mice treated with Cs after development of glucose intolerance showed severe insulitis and a marked decrease in the number of Langerhans' islets. The pancreata of the glucose intolerant mice that obviously did not develop hyperglycaemia also revealed severe insulitis.

\section{Discussion}

The present study clearly shows that development or exacerbation of diabetes in NOD mice is prevented by administration of $\mathrm{Cs}$ if the treatment is started when insulitis is absent or minimal. This conclusion is in complete agreement with the report of Laupacis et al. [7], 
who showed that the development of insulin-dependent diabetes mellitus in BB Wistar rats was suppressed by Cs.

Unfortunately, Cs was not effective in ameliorating diabetes in NOD mice after development of clear glucose intolerance. Stiller et al. [9] reported that Cs was effective in 16 out of 30 insulin-dependent diabetic patients to whom Cs was administered within 6 weeks after diagnosis. In contrast, $\mathrm{Cs}$ was effective in only two cases out of 11 when it was given 8 to 44 weeks after diagnosis. Taken collectively, these results suggest that Cs is effective in cases of insulin-dependent diabetes mellitus of recent onset, i.e. in which Langerhans' islets are not totally destroyed.

The mechanism by which Cs prevents the development of diabetes is unclear at present. However, since the majority of mononuclear cells surrounding and/or invading the Langerhans' islets of NOD mice are reported to be $\mathrm{T}$ cells, which play an important role in the inflammation at an early stage [10], Cs may terminate the insulitis by removing the $\mathrm{T}$ cells.

Acknowledgement. The authors are grateful to Dr. A. Lernmark (Hagedorn Research Laboratory, Denmark) for his review of this manuscript.

\section{References}

1. Tochino $Y$, Kanaya T, Makino S (1982) Genetics of NOD mice. In: Mimura G, Baba S, Goto Y, Kobberling J (eds) Clinicogenetic genesis of diabetes mellitus. Excerpta Medica, Amsterdam, pp 285-291
2. Borel JF, Feuer C, Gubber HM, Stahelin H (1976) Biological effects of cyclosporin A: a new antilymphocytic agent. Agents Action $4: 468-475$

3. White DJ, Rolles K, Ottawa T, Turell O (1980) Cyclosporin A induced long term survival of fully incompatible skin and heart graft in rats. Transplant Proc 12:261

4. Homan WP, Williams KA, Millard PR, Morris PJ (1981) Prolongation of renal allograft survival in the rat by pretreatment with donor antigen and cyclosporin A. Transplantation (Baltimore) 31: 423

5. Gratwohl A, Forster I, Speck B (1981) Skin grafts in rabbits with cyclosporin A: absence of induction of tolerance and outward side effects. Transplantation (Baltimore) 32: 349

6. Tutschka PJ, Beshorner WE, Allison AC, Burns WH, Santos GW (1979) Use of cyclosporin A in allogenic bone marrow transplantation in the rat. Nature (Lond) 20: 148

7. Laupacis A, Stiller CR, Gardell C, Keown P, Dupre J, Wallace, Thibert $P$ (1983) Cyclosporin prevents diabetes in BB Wistar rats. Lancet 1: 10-11

8. Okuda J, Miwa I, Maeda K, Tokui K (1977) Rapid and sensitive, colorimetric determination of the anomers of d-glucose with oxidase, peroxidase and mutarotase. Carb Res 58: 267

9. Stiller CR, Dupre J, Gent M, Jenner MR, Keown PA, Laupacis A, Martell R, Rodger NW, Graffenried BV, Wolfe BMJ (1984) Effects of cyclosporin immunosuppression in insulin-dependent diabetes mellitus of recent onset. Science 223: 1362-1367

10. Miyazaki A, Hanafusa T, Yamada K, Miyagawa J, Nakajima $H$, Nonaka K, Tarui S (1985) Predominance of T lymphocytes in pancreatic islets and spleen of pre-diabetic non-obese diabetic (NOD) mice: a longitudinal study. Clin Exp Immunol 60; 622-630

Received: 27 June 1985

and in revised form: 17 February 1986

Dr. Hirokazu Okudaira

Department of Medicine and Physical Therapy

The University of Tokyo

7-3-1 Hongo, Bunkyo-ku

Tokyo 113, Japan 